\title{
Replication and pathogenesis of white sturgeon iridovirus (WSIV) in experimentally infected white sturgeon Acipenser transmontanus juveniles and sturgeon cell lines
}

\author{
L. R. Watson ${ }^{1}$, J. M. Groff ${ }^{2}$, R. P. Hedrick ${ }^{1, *}$ \\ ${ }^{1}$ Department of Medicine and Epidemiology, School of Veterinary Medicine, University of California, Davis, \\ California 95616, USA \\ ${ }^{2}$ Department of Pathology, Microbiology and Immunology, School of Veterinary Medicine, University of California, \\ Davis, California 95616, USA
}

\begin{abstract}
Characteristics of the in vitro propagation of the white sturgeon iridovirus (WSIV) were examined in 6 sturgeon cell lines. One new cell line originating from gonadal tissues (WSGO) produced up to 12 -fold more WSIV [ 22 TCID $50\left(50 \%\right.$ tissue culture infective dose) cell $\left.{ }^{-1}\right]$ than that of a previously established reference spleen cell line (WSS-2). Infected WSGO cell cultures were examined using phase microscopy, viral infectivity assay and transmission electron microscopy (TEM). At $15^{\circ} \mathrm{C}$, both mature virions and infectious virus were first detected after $7 \mathrm{~d}$ post-infection. Capsids acquired envelopes in the cytoplasm and virions remained primarily cell-associated during the $35 \mathrm{~d}$ replication cycle. Cellular changes including hyper-refractility and cytoplasmic swelling with dense cytoplasmic inclusions correlated to extensive proliferation of cytoplasmic vesicles and viral assembly sites. These cytological characteristics corresponded to changes in target cells of WSIV-infected juvenile white sturgeon following bath challenge. Microscopic changes in stained tissue sections of the host epithelium were detected $4 \mathrm{~d}$ post-challenge, approximately $8 \mathrm{~d}$ prior to the onset of clinical signs. Hypertrophied Malpighian cells surrounded by a prominent pericellular cisternum characterized epithelial lesions in the skin. Similar changes to epithelial cells of the barbels, olfactory organs and esophagus were also observed. Destruction of the sensory epithelium is suggested as a cause for cessation of feeding which occurs early in the infection of white sturgeon juveniles with WSIV.
\end{abstract}

KEY WORDS: Sturgeon · Iridovirus · Virus

\section{INTRODUCTION}

Catastrophic losses associated with pathogenic iridoviruses in both marine and freshwater cultured fishes pose a major threat to the economic viability of aquacultural operations worldwide (Ogawa et al. 1990. Hyatt et al. 1991, Hedrick et al. 1992a, Nakajima et al. 1995). Viral diseases of white sturgeon Acipenser transmontanus have recently been recognized as significant obstacles to the emerging sturgeon aquaculture industry in northern California and Idaho, USA

·Addressee for correspondence.
E-mail: rphedrick@ucdavis.edu
(Hetrick \& Hedrick 1993, LaPatra et al. 1994). The white sturgeon iridovirus (WSIV) is associated with a chronic debilitating wasting syndrome which results in severely impaired growth and reduced survival of fry and fingerlings (Conte et al. 1988, Hedrick et al. 1990, PSMFC 1992). The eventual control of commercially devastating fish pathogens like WSIV will require sensitive pathogen detection methods in addition to rigorous fish health management strategies based on a thorough knowledge of the virus and the disease process (Carey \& Pritchard 1995).

In vitro studies of WSIV have provided a preliminary understanding of viral pathogenesis related to temperature and host cell range (Hedrick et al. 1992b). How- 
ever, the relatively narrow temperature range, slow replication rate and low amounts of virus produced in established coll lines have hampered further investigations (Hedrick et al. 1991). Improving in vitro propagation of WSIV using newly developed cell lines was one goal of our laboratory research.

The in vitro characteristics of certain viruses may be correlated with their pathogenic effects on the host. An emerging group of iridoviruses related to the amphibian virus FV-3 in the Ranavirus genus of the family Iridoviridae (Aubertin 1992) have been associated with acute and lethal infections in several fish species (Hedrick et al. 1992a, Hengstberger et al. 1993). Several of these agents cause rapidly lytic infections in cell cultures originating from a wide range of hosts including, fish, amphibian and mammals. Lymphocystivirus, a second genus in the family Iridoviridae, contains the fish lymphocystis disease viruses, or FLDV, which are generally refractory to long-term propagation in cell cultures (Walker \& Hill 1980). Infections with FLDV are commonly associated with a chronic and recurrent disease that debilitates but rarely kills its marine or freshwater fish host (Anders 1989). While certain properties of WSIV resemble most closely those of FLDV, the disease associated with the sturgeon virus is more serious and lethal, as found with the systemic iridoviruses. The present study was therefore undertaken to examine in more detail both in vitro and in vivo properties of experimentally induced infections with WSIV as they compare to what is currently known of other members of the Iridoviridae found in fish.

\section{METHODS}

Sturgeon cell lines. To establish primary sturgeon cell cultures, tissues from the olfactory organ, brain, swim bladder, liver, meningeal myeloid organ or cranial hematopoietic/granulopoietic organ (Fänge 1986) and gonad were aseptically removed from a yearling sturgeon. Tissues were minced in separate petri dishes containing Earle's Minimum Essential Medium and $10 \%$ fetal calf serum buffered with N-2-hydroxyethylpiperazine-N-2-ethanesulfonic acid (MEM-10-HEPES) supplemented with antibiotics $\left(200 \mathrm{IU} \mathrm{m}^{-1}\right.$ penicillin and $200 \mu \mathrm{g} \mathrm{ml}^{-1}$ streptomycin) prior to transfer to a 12 -well tissue culture plate. The plates were incubated at $15^{\circ} \mathrm{C}$ until adherent cells were observed ( 1 to $4 \mathrm{wk}$ ), after which time residual tissue debris was rinsed away and fresh medium was added (Hedrick et al. 1991). Confluent cell layers were trypsinized and passaged to larger flasks $\left(25 \mathrm{~cm}^{2}\right)$. Initially, primary tissue cultures contained several morphologically distinct cell populations but they became more homogeneous after 5 to 10 passages. After the 20th serial passage, cell cultures that showed approximately $95 \%$ or greater cell homogeneity and were stable to subculture were considered established lines. After 40 passages, cells from selected cultures were serially diluted for the production of cloned cell lines. For long-term storage, aliquots of the cell lines were suspended in $10 \%$ dimethylsulfoxide in MEM-10 and frozen at $-120^{\circ} \mathrm{C}$. The cell lines obtained from our studies were designated WSGO, WSHO, WSLV, WSSB and WSNV for gonad, meningeal myeloid organ, liver, swim bladder and brain, respectively. The previously established WSS-2 line also used in this study was derived from white sturgeon spleen tissues (Hedrick et al. 1991) and was propagated under similar conditions to newly established cell lines.

Comparative WSIV replication in sturgeon cell lines. Five estabiished celi iines were compared for optimal WSIV replication. The reference WSS-2 line and duplicate $25 \mathrm{~cm}^{2}$ flasks of the new cell lines from gonad (WSGO), brain (WSNV), swimbladder (WSSB), meningeal myeloid organ (WSHO) and liver (WSLV) were inoculated at a multiplicity of infection (MOI) $\approx 0.1 \mathrm{TCID}_{50}\left(50 \%\right.$ tissue culture infective dose) cell ${ }^{-1}$, the minimum dose necessary to initiate progressive infections (authors' unpubl. results). The mean number of cells in each flask at the time of inoculation ranged from $10^{6.0}$ (WSS-2 or WSGO) to $10^{6.15}$ (WSSB). Cell counts were conducted on separate replicate flasks by trypsinizing and resuspending the cell layer prior to cell counts in a hemacytometer. The concentration of the $1.0 \mathrm{ml}$ inoculum was adjusted so that all cell lines received the same MOI. The amount of virus in combined supernatants and homogenized cell extracts (see below) was calculated and converted from TCID $50 \mathrm{ml}^{-1}$ to $\mathrm{TCID}_{50} \mathrm{Cell}^{-1}$ (Reed \& Muench 1938). Net virus concentrations at the end of the 4 wk period following inoculation were calculated by subtracting the inoculum dose from the final virus concentration measured.

Virus production assays. The WSGO cell line was selected for further study of the viral multiplication cycle. WSIV production at $15^{\circ} \mathrm{C}$, the optimum temperature for in vitro WSIV replication (Hedrick et al. 1992b), was then measured by infectivity assay at selected time intervals up to $42 \mathrm{~d}$, after which significant viral replication ceased. Two duplicate $25 \mathrm{~cm}^{2}$ flasks, each with $90 \%$ confluent cell lines, were prepared for each of 5 sampling intervals at $t$ (time) $=2,7$. 14, 21 and 42 d post-infection (PI). Separate sets of 6 -well plates were similarly prepared solely for phase and electron microscopic (TEM) examinations at 2, 7, 14 and $21 \mathrm{~d}$ PI. To calculate the TCID $50 \mathrm{cell}^{-1}$, cell counts were obtained from 2 uninfected replicate flasks of WSGO cells as described previously. Cell monolayers either in $25 \mathrm{~cm}^{2}$ flasks or in 6 -well plates were inoculated at the same time $(t=0)$ at a $\mathrm{MOI} \approx 0.1$. The medium was removed after $1 \mathrm{~h}$, the monolayers 
were rinsed once with MEM with no fetal bovine serum (MEM-0) prior to addition of fresh MEM with $2 \%$ fetal bovine serum buffered with HEPES (MEM$2-\mathrm{H}$ ). Concentrations of WSIV were then measured in randomly sampled duplicate flasks at the prescribed sampling intervals.

At each sampling period the supernatants were decanted from duplicate $25 \mathrm{~cm}^{2}$ flasks; the cells were then rinsed 3 times with $1 \mathrm{ml}$ MEM-0 and the rinses were added to the supernatant fraction. Suspended cells were removed from the supernatant by centrifugation at $500 \times g$, the supernatant was removed, the cells were resuspended in $50 \mu \mathrm{l}$ of MEM-0, then added back to the flask containing the monolayer. Attached cells were scraped from the substrate, resuspended in $1 \mathrm{ml}$ MEM-0, removed from the flask and disrupted by 10 strokes in a tight-fitting Ten Broek homogenizer. Serial 10-fold dilutions of supernatant and cell homogenates in MEM-2-H were used to inoculate WSS-2 cells in 96-well plates as previously described (Hedrick et al. 1992b). Final virus concentrations were calculated on the basis of TCID $50 \mathrm{ml}^{-1}$ and converted to $\mathrm{TCID}_{50}$ cell $^{-1}$, based on the initial cell counts.

Phase and electron microscopy. Cells propagated in the 6-well dishes (as mentioned above) were examined daily for evidence of cytopathic effects (CPE) using an inverted phase contrast microscope. Additional replicate wells were fixed for TEM by rinsing the monolayer 2 times with MEM-0 and then adding $2.5 \%$ glutaraldehyde in $0.06 \mathrm{M}$ cacodylate buffer ( $\mathrm{pH} 7.4$ ) for $4 \mathrm{~h}$ at $4^{\circ} \mathrm{C}$. The cells fixed as a monolayer were rinsed twice in buffer and then post-fixed in $1 \%$ aqueous $\mathrm{OsO}_{4}$, dehydrated through a graded ethanol series, infiltrated and embedded in epoxy resin. Thin sections ( 60 to $90 \mathrm{~nm}$ ) were stained with $2 \%$ uranyl acetate and lead citrate prior to examination with a Phillips EM 400 electron microscope at $80 \mathrm{kV}$.

Experimental infections. Experimental WSIV infections were initiated by immersing fish in an aqueous suspension of the freshly harvested virus. Virus was prepared by inoculating ten $150 \mathrm{~cm}^{2}$ flasks of WSS-2 monolayers at a $\mathrm{MOI} \approx 0.1$. After a $4 \mathrm{wk}$ incubation period at $15^{\circ} \mathrm{C}, \mathrm{CPE}$ was complete and the infected cells and fluid contents were harvested. Cells were pelleted by centrifugation at $1000 \times g$ for $10 \mathrm{~min}$ and disrupted with a Ten Broek homogenizer. The cell extract was then mixed with the supernatant and used for challenges of juvenile white sturgeon. The virus stock was diluted 1:20 in water to a total volume of $3.9 \mathrm{l}$ and divided equally between three $5 \mathrm{l}$ containers. The diluted challenge bath contained approximately $500 \mathrm{TCID}_{50} \mathrm{ml}^{-1}$ based on back-titration of the undiluted virus inoculum. Three similar control containers were prepared with MEM-2 diluted 1:20 in ambient well water.
Approximately 300 healthy white sturgeon fry averaging $0.6 \mathrm{~g}$ in weight and $6.0 \mathrm{~cm}$ in length were graded from a stock population and maintained in a $300 \mathrm{l}$ aquarium. Fish were fasted for $24 \mathrm{~h}$ prior to challenge to reduce wastes during virus exposures. Fish were then removed from the large aquarium and distributed randomly to six 51 aerated containers prepared with the challenge or control baths at $17^{\circ} \mathrm{C}$. Virus exposure continued for 45 min after which fish in each container were transferred to separate 20 l aquaria receiving fresh aerated well water at a flow rate of $0.51 \mathrm{~min}^{-1}$ at 16 to $18^{\circ} \mathrm{C}$. Routine feeding of a trout fry diet (Clear Springs Foods, Inc., Buhl, Idaho, USA) fed at a rate of $5 \%$ body weight $\mathrm{d}^{-1}$ was resumed the day after the challenge.

Fish sampling. One week prior to challenge, 25 fish $(0.5 \mathrm{~g})$ were randomly netted from the stock aquarium to obtain samples for baseline histology and confirmation of virus-free status. Following the challenge, live fish were randomly sampled for either viral infectivity assay (5 fish daily) or histological examination (4 fish daily) for up to $25 \mathrm{~d}$, at which time the experiment was terminated.

Virus titrations. Fish collected daily for virus titrations were euthanized by a brief immersion in $500 \mu \mathrm{g}$ $\mathrm{ml}^{-1}$ tricaine methanesulfonate. Whole blood was collected in heparinized microcapillary tubes following caudal amputation and transferred to a clean plastic vial. Gills were aseptically removed from each fish and then a median abdominal incision was made to expose and remove visceral organs including liver, spleen, esophagus and kidney. Due to the small size of the fish it was necessary to pool homologous tissues from all 5 fish on each sampling day. Dissection instruments were flame sterilized between each set of organs. Pooled tissues or blood were diluted in MEM-2 with antibiotics at an approximate weight:volume ratio of $1: 2$. Tissues were extracted by several strokes in a loose-fitting Ten Broek homogenizer. Following overnight incubation at $4^{\circ} \mathrm{C}$, samples were centrifuged for $10 \mathrm{~min}$ at $1000 \times g$ to remove debris. Gills, esophagus and blood were diluted 1:25 and spleen, kidney and liver samples were diluted 1:75 to avoid cytotoxic effects. Duplicate 24-well tissue culture plates containing WSS-2 cells were inoculated with $0.2 \mathrm{ml}$ of the diluted tissue extracts in each well and incubated at $25^{\circ} \mathrm{C}$ for $1 \mathrm{~h}$. Each well was then overlaid with $0.5 \mathrm{ml}$ MEM-2-H and the plates incubated at $15^{\circ} \mathrm{C}$. Plates were examined once a week for CPE over a period of 8 wk. Two negative control (0.2 ml MEM-2-H) wells of WSS-2 cells were included on each plate.

Microscopic examinations. Four fish were arbitrarily collected and euthanized on each sample day. After making an incision to expose internal organs, the fish were immediately placed in Bouin's fixative (Humason 
1979). Carcasses were fixed at $25^{\circ} \mathrm{C}$ for 12 to $24 \mathrm{~h}$ prior to storage in $70 \%$ ethanol. Fixed whole fish were embeddcd in paraffin, sectioned and stained with hematoxylin and eosin using standard protocols for histology (Humason 1979).

\section{RESULTS}

\section{Sensitivity of sturgeon cell lines to WSIV}

Differences in morphology and growth rates were apparent within a few days after adherent cell populations were established from the primary tissue cultures. WSGO cells were similar in size and growth to WSS-2 cells and formed a uniform monolayer whereas WSSB cells were smaller in size, grew more slowly and formed irregular monolayers. There was a wide range of WSIV production between the newiy derived sturgeon cell lines (Table 1) including an approximately 300-fold difference in virus concentration between the highest (WSGO) and the lowest (WSSB) virus producers. In addition, the WSGO line produced approximately 12 -fold more virus per cell compared to the reference WSS-2 line

\section{Cytopathic effects}

The microscopic appearance of uninfected WSGO cell cultures (Fig. 1A) closely resembled that of WSS-2 (data not shown). The minimum MOI to obtain a progressive infection was 0.1 , which resulted in the formation of approximately 1 pseudosyncytium (focal area of infected cells) per 300 cells in the absence of cytoplasmic inclusion bodies. Major cytopathological changes observed by phase microscopy that occurred during the 1-step WSIV multiplication cycle were di-

Table 1. Acipenser transmontanus. Net cumulative production of white sturgeon iridovirus (WSIV) in the reference WSS-2 and 5 newly derived sturgeon cell lines, TCID $50: 50 \%$ culture infective dose; SP: spleen; GO: gonad; $\mathrm{HO}$ : cranial hematopoietic organ; LV: liver; BR: brain; SB: swim bladder - Significantly higher than reference cell line (Tukey's HSD $t$-test, $\alpha=0.05)$. ND: not done

\begin{tabular}{|lccrrrrr}
\hline \multirow{2}{*}{ Organ } & $\begin{array}{c}\text { Cell } \\
\text { line }\end{array}$ & $\begin{array}{c}\text { Passage } \\
\text { no. }\end{array}$ & \multicolumn{4}{c}{ Net virus titer } \\
Trial 1 & Trial 2 & Trial 3 & Cell & Mean \\
SP & WSS-2 & 70 & 1.3 & 1.8 & 2.8 & 1.97 \\
GO & WSGO & 24 & 15.1 & 29.5 & ND & $22.30^{\circ}$ \\
HO & WSHO & 22 & ND & 7.7 & 6.6 & $7.15^{\circ}$ \\
LV & WSLV & 22 & 0.9 & 1.5 & ND & 1.20 \\
BR & WSNV & 20 & 0.6 & ND & 0.5 & 0.55 \\
SB & WSSB & 22 & ND & 0.1 & 0.1 & 0.10 \\
& & & & & & \\
\hline
\end{tabular}

visible into 3 sequential, partially overlapping phases. (1) Early phase $(0$ to $7 \mathrm{~d}$ ): the first observed features included slightly enlarged, widely dispersed individual cells which contrasted with the uniform monolayer of uninfected cells (Fig. 1B). The center of the infected cell was accentuated by hyperchromatic, granular or vacuolated regions surrounding a highly refractile apical ridge. (2) Intermediate phase (8 to $14 \mathrm{~d}$ ): infected cells continued to enlarge and coalesce into multicellular aggregates (Fig, 1C). Cell shapes ranged from rectangular to triangular, polygonal, columnar and/or ellipsoidal, the nuclei contained dense inclusions and were fragmented, lobulated, hypertrophied and/or pyknotic. A striking feature of infected cells was the elongated, hyperchromatic, branched and/or attenuated pseudopods. (3) Late phidse (15 to 21 d). the stage when most of the virus was produced was characterized by the formation of pseudosyncytia composed of focal multicellular clusters of enlarged cells. The pseudosyncytium differs from the true syncytium because a true polykaryocyte is not formed (Fig. 1D). WSIV infections may require 4 to $6 \mathrm{wk}$ to produce pseudosyncytia and at a $\mathrm{MOI}<0.1$ the infection may not progress to the remaining monolayer.

A rapid initial increase in the number and size of intracytoplasmic vesicles observed by TEM (Fig. 2A) was correlated with enhanced refractility revealed by phase microscopy. The presence of dense granules, degenerative membranes and lysed mitochondria in the vicinity of the vesicles was suggestive of their lysosomal function. Microscopic changes that included hypertrophy, increased refractility and highly deformed pseudopods by phase contrast microscopy roughly coincided with the appearance of virions in the cytoplasm as observed by TEM between 7 and $14 \mathrm{~d}$ PI (Fig. 2B). By 14 d PI, enveloped virions averaging $302 \pm 11.2 \mathrm{~nm}$ in diameter $(\mathrm{n}=30$ ) appeared in the cytoplasm while unencapsidated cores (nucleoids) and unenveloped capsids were rarely observed. Aggregates of viral capsids in various stages of development were observed in close association with a spherical body resembling an enlarged trans Golgiapparatus (Fig. 2C). There were amorphous virus-like particles, with or without envelopes, as well as empty or incomplete capsids with or without cores, distributed around the periphery of this putative viral assembly site (AS). Outer virion envelopes were composed of 2 closely apposed unit membranes closely resembling the membranous lamina of the AS. Although enveloped virions were abundant in the cytoplasm, no direct evidence of envelopment, either in the AS or plasma membrane, were observed. The plasma membranes of infected cells remained intact up to $21 \mathrm{~d}$ PI and budding and cell Iysis were not observed. 

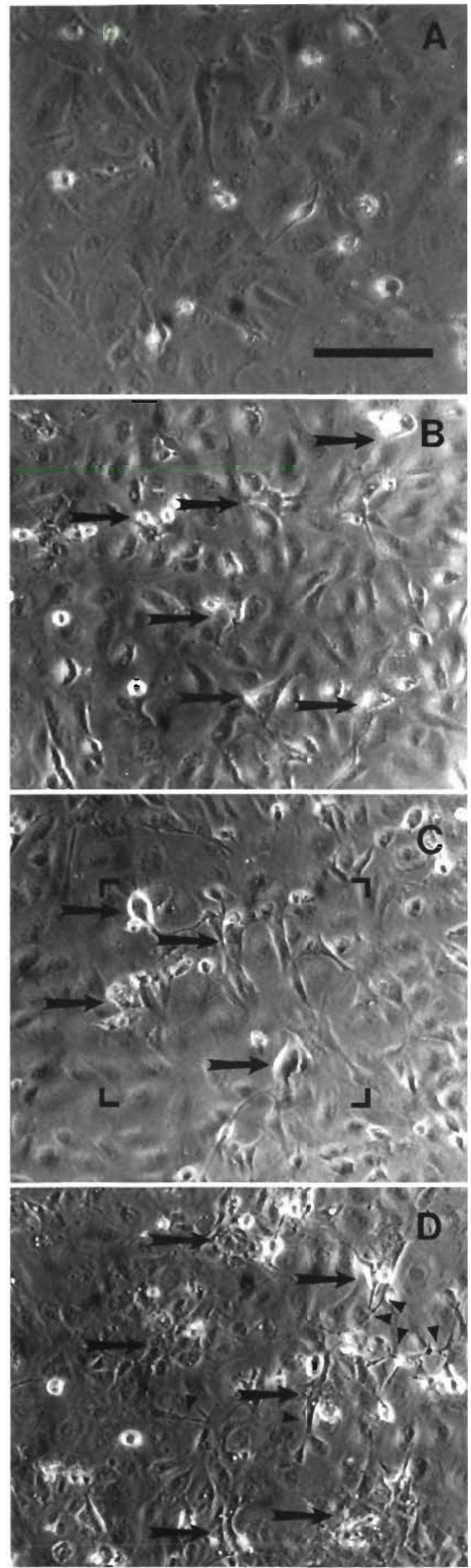

Cross-sections of virions revealed 5 distinct regions of high density (Fig. 2D). The bar-shaped nucleoid was surrounded by a granular or bead-like membrane that morphologically resembled nearby vesicular membranes but was dissimilar to the capsid envelope. Nucleoids $(n=30)$ ranged in size from 90 to $150 \mathrm{~nm}$ and contained a spool-like filamentous strand which varied in density from semi-transparent $(120 \times 150 \mathrm{~nm})$ to opaque $(90 \times 150 \mathrm{~nm})$.

\section{WSIV production assays}

The presence of cell associated (intracellular) WSIV was first detected by infectivity assay at $7 \mathrm{~d}$ PI after which production rapidly increased (Fig. 3). By the end of the study at $42 \mathrm{~d}$ PI virus production was approximately 6-fold higher in WSGO cells as compared to WSS-2 cells. Infectious virus remained principally cell associated throughout the study and was not detected in the culture supernatant until $20 \mathrm{~d}$ PI in WSGO cells and $14 \mathrm{~d}$ PI in the WSS-2 cells. The proportion of total virus produced that was released to the extracellular medium was $8 \%$ by WSGO cells compared to $8 \%$ by the WSS- 2 cells.

\section{Experimental infections of juvenile white sturgeon}

The WSIV challenge dose of 500 TCID $_{50} \mathrm{ml}^{-1}$ $\left(10^{4.3}\right.$ TCID $_{50} g^{-1}$ of fish) was sufficient to initiate infections in the majority of white sturgeon juveniles. The behavior and appearance of fish exposed to WSIV was similar to that of control fish up until 10 to $14 \mathrm{~d}$ postchallenge (PC), when lethargy, erratic swimming and inappetence were first noted. Control fish fed actively at the surface, in the water column and on the tank bottom throughout the study. In contrast to controls, affected fish were often darker in color, slow to respond or indifferent to food and displayed varying degrees of emaciation. By $3 \mathrm{wk}$ PC 10 to $20 \%$ of challenged fish were showing severe emaciation and

Fig. 1. Acipenser transmontanus. Phase photomicrographs depicting salient features of cytopathic effects during early to intermediate stages of infection induced by the white sturgeon iridovirus (WSIV) during a 1-step multiplication cycle in the WSGO cell line. (A) Uninfected control. (B) $7 \mathrm{~d}$ postinfection (PI). Cytoplasmic swelling and hyper-refractility of individual infected cells (arrows). (C) $14 \mathrm{~d}$ Pl. Enlargement and partial fusion of adjacent infected cells (arrows) form aggregates which will later coalesce into a pseudosyncytium [box]. (D) $21 \mathrm{~d}$ PI. Cells within the pseudosyncytium (large arrows) show dense, attenuated, tubular and/or branched pseudopodia (arrowheads). Scale bar $=200 \mu \mathrm{m}$ 

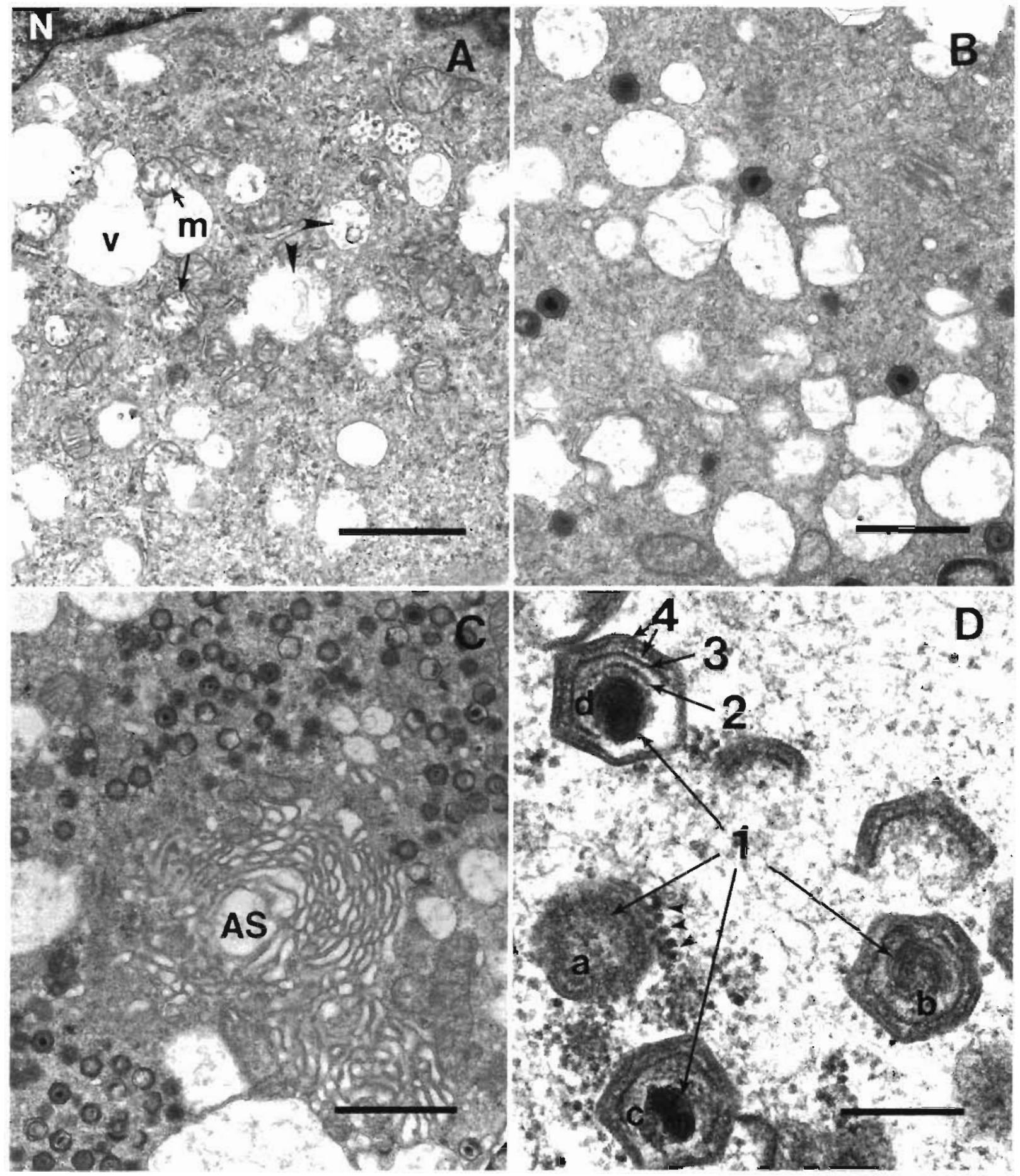

Fig 2 Acipenser transmontanus Transmission electron micrographs of WSGO cells during a viral production assay of white sturgeon iridovirus (WSIV) showing ultrastructural detaıls of viral morphogenesis (A) $7 \mathrm{~d}$ PI. Nucleus (N) and adjacent cytoplasm showing extensive proluferation and enlargement of vesicles (v) resembling lysosomes (note membrane fragments (arrowheads) and degenerative mitochondna $(\mathrm{m}) \mid$ Scale bar $=1 \mu \mathrm{m}(\mathrm{B}) 14 \mathrm{~d}$ PI Icosahedral vinons containing a bar-shaped core (nucleoid) were first observed in the highly vesicularized cytoplasm midway between the nucleus and the plasmalemma. Scale bar $=1 \mu m$ (C) $14 \mathrm{~d}$ PI A putative viral assembly site (AS) consisted of concentncally arranged double unit membranes in the near vicinity of virus particles in various stages of development Scale bar $=2.5 \mu \mathrm{m}$ (D) $14 \mathrm{~d}$ PI. Four possibly sequential morphogenic stages of WSIV (a) nascent nucleoprotein core, partıally enclosed by a double envelope (opposite vertices), associated with a polyribosome-like structure (arrowheads), (b) electron-lucent filamentous core enclosed by a double-enveloped capsid; (c) condensed, bar-shaped core; (d) mature virion, showing 4 concentric dense layers surrounding the nucleoid (1); (2) granular nucleoid envelope, (3) hexagonal capsid shell and (4) inner and outer lamina of the capsid envelope. Scale bar $=300 \mathrm{~nm}$ 
Fig. 3. Acipenser transmontanus. Multiplication of the white sturgeon iridovirus (WSIV) in WSS-2 or WSGO cells comparing replication rates, cumulative virus production and intracellular (cell) or extracellular (sup) virus distribution. $\mathrm{TCID}_{50}$ : $50 \%$ culture infective dose
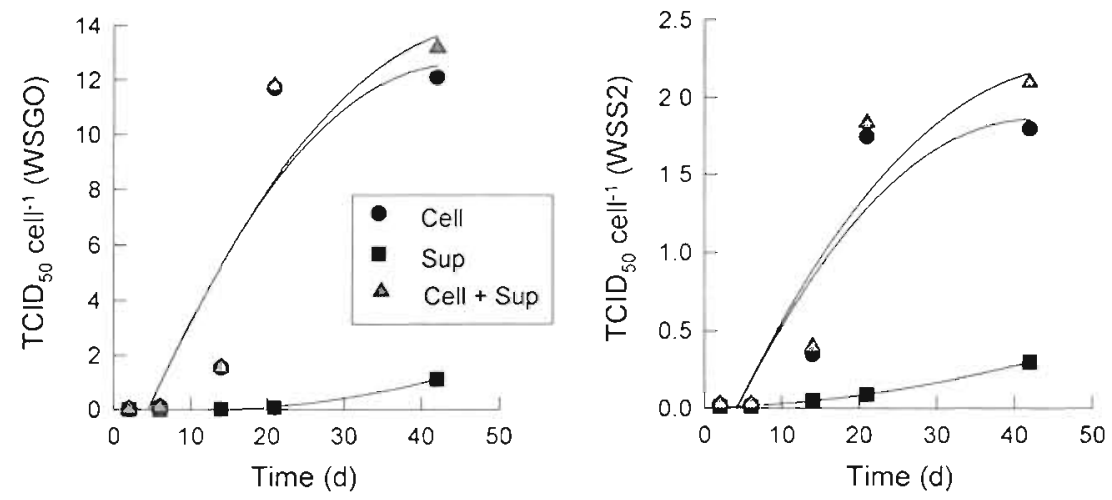

lethargy, 30 to $60 \%$ were moderately emaciated but active and 20 to $40 \%$ appeared normal from both behavioral and clinical aspects. Although WSIV infections were rarely characterized by external lesions, necropsy examinations revealed 50 to $75 \%$ of severely emaciated fish displayed variable swelling and pallor of the gills, flared or swollen nasal apertures, atrophied and/or hyperchromatic (dark brown) livers and empty intestinal tracts, including the spiral valve. Wet mount examination of scrapings from the skin and gills of challenged fish revealed occasional bacterial (Flavobacterium spp.) and/or fungal (Saprolegnia spp.) infections which were mostly confined to the caudal peduncle and caudal fin.

The temporal presence of microscopic lesions corresponded with the isolation of infectious virus from these tissues (Table 2). Involvement of the olfactory organ (rosette) was observed in many fish and this preceded the presence of lesions in previously known target tissues in the gill and skin. The olfactory rosette is an opaque lobulated structure found in the concave aspect of the nasal aperture. The 6 finger-like lamellae with sensory epithelium radiate like spokes from a central proximal hub and are connected at the distal ends to the epithelial lining of the rim of the nasal pit (Fig. 4A). Following WSIV infection the olfactory lamellae became thickened and dysplastic (Fig. 4B). The lamellar mucosa is comprised of pseudostratified columnar epithelium rarely more than 3 cells in thickness (Fig, 4C). Apical cells are ciliated and the brush border is contiguous over the entire lamellar surface. Goblet (mucus) cells may be found congregated at the tips and crypts of the lamellae. The lamellar mucosa was a target of early WSIV infection as infected cells in the epithelium showed typical signs including nuclear and cytoplasmic enlargement, amphophilic staining properties and the loss of apical cilia (Fig. 4D).

Microscopic changes typical of WSIV infection were also observed in the epithelium of the barbels, esophagus, gills and skin (Fig. 5A to D). Skin lesions were mostly confined to the cranial region, although fin lesions were occasionally observed. Lesions were also observed in the oropharygeal cavity including the hard palate, tongue, lips and opercular flap (Fig. 5B) Infected cells in all tissues were variably enlarged, up to $3 \times$ normal $(75 \mu \mathrm{m})$ and focal hyperplasia was occasionally observed in cells in the near vicinity. A prominent feature common to all infected tissues was the translucent pericellular cisternum, measuring from 10 to $20 \mu \mathrm{m}$ in width (compared to $1 \mu \mathrm{m}$ between normal

Table 2. Acipenser transmontanus. Results of microscopic examinations of hematoxylin/eosin stained tissue sections from juvenile white sturgeon following bath challenge with white sturgeon iridovirus (WSIV). Clinical signs of WSIV infection were observed beginning at -12 d post challenge. OO: olfactory organ; G: gill; Sk: skin; E: esophagus; K: kidney; L: liver; Sp: spleen. + : positive (1 or more fish); 0 : negative; ND: not done

\begin{tabular}{|c|c|c|c|c|c|c|c|c|c|c|c|c|c|}
\hline \multirow{2}{*}{ Tissue } & \multicolumn{13}{|c|}{ Time post-challenge (d) } \\
\hline & 1 & 3 & 4 & 5 & 6 & 7 & 8 & 10 & 12 & 14 & 18 & 20 & 25 \\
\hline 00 & 0 & 0 & + & + & ND & + & ND & ND & ND & ND & + & ND & + \\
\hline$G$ & 0 & 0 & 0 & + & 0 & + & + & + & ND & + & $\mathrm{ND}$ & + & + \\
\hline Sk & 0 & 0 & 0 & + & ND & ND & + & ND & + & ND & + & ND & + \\
\hline$E$ & 0 & 0 & 0 & 0 & + & + & 0 & + & ND & + & ND & + & + \\
\hline $\mathrm{K}$ & 0 & 0 & ND & 0 & 0 & 0 & ND & 0 & $\mathrm{ND}$ & 0 & ND & 0 & 0 \\
\hline $\mathrm{L}$ & 0 & 0 & 0 & 0 & 0 & 0 & ND & ND & 0 & 0 & 0 & 0 & 0 \\
\hline $\mathrm{Sp}$ & 0 & 0 & ND & 0 & 0 & 0 & ND & 0 & ND & 0 & $\mathrm{ND}$ & 0 & 0 \\
\hline
\end{tabular}




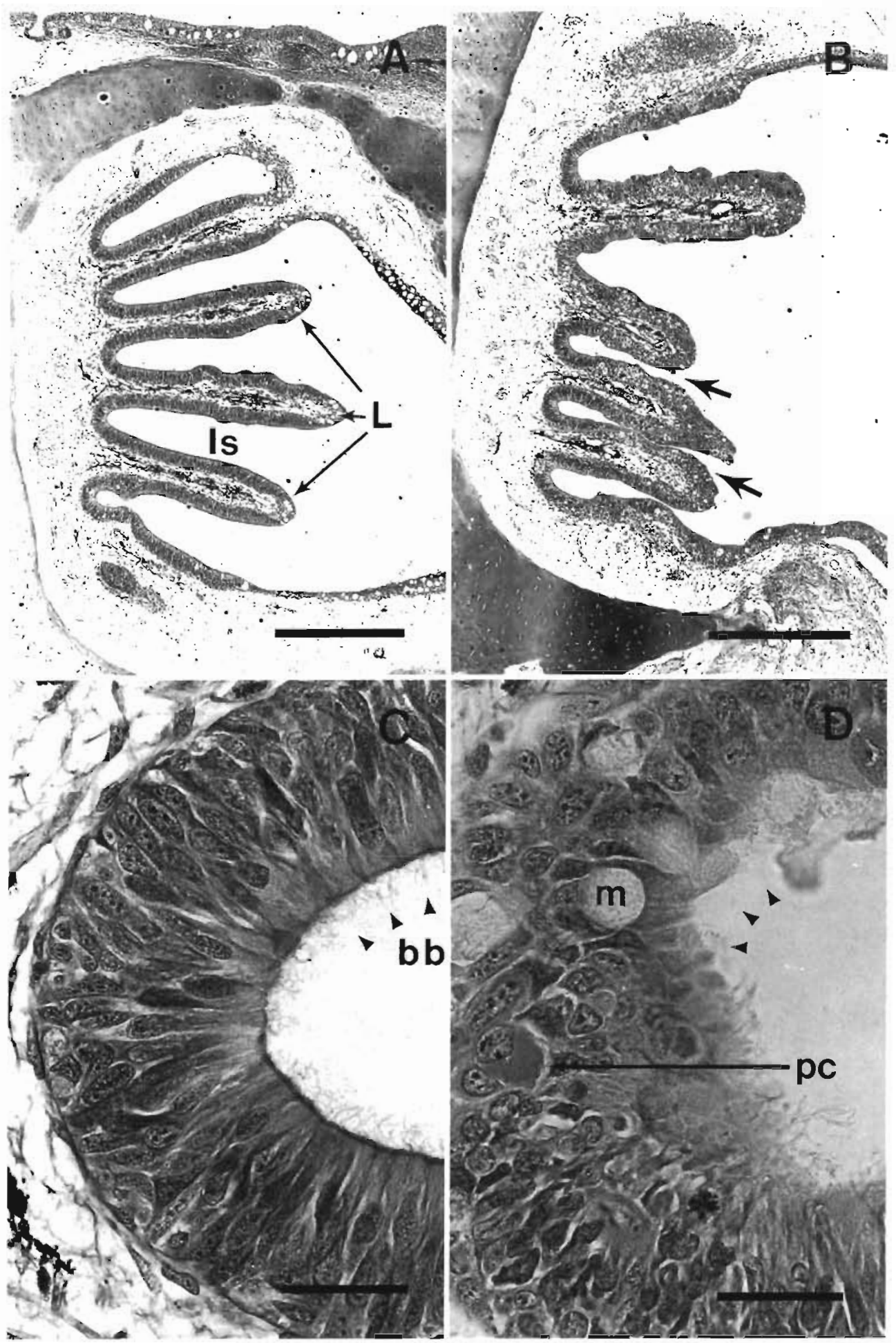

Fig. 4. Acipenser transmontanus. Light micrographs of hematoxylin/eosin stained sections of the olfactory rosette from white sturgeon juveniles bath-challenged with white sturgeon iridovirus (WSIV). (A) Control fish 18 d post-challenge (PC), showing pseudostratified columnar epithelium of the olfactory lamellae (L). Width of interlamellar space (Is) is approximately the same as the lamellae. Scale bar $=100 \mu \mathrm{m}$. (B) WSIVchallenged fry $18 \mathrm{~d}$ PC, showing thickening of the mucosa and subsequent closure of interlamellar spaces (arrows). Lamellae are swollen and truncated and the epithelium is hyperplastic, dysplastic and focally necrotic. Scale bar = $100 \mu \mathrm{m}$. (C) Control fish (5 d $\mathrm{PC}$ ) showing the normal appearance of the brush border (bb) lining of the lamellar crypt. Scale bar $=$ $20 \mu \mathrm{m}$. (D) Infected fish (5 d PC) demonstrating prominent features of early lesions, including swollen and hyperchromatic cytoplasm of an infected cell surrounded by a translucent pericellular cisternum (pc). The lamellar brush border (arrowheads) is severely disrupted and dysplastic. $\mathrm{m}$ : mucus cell. Scale bar $=$ $20 \mu \mathrm{m}$

cells) surrounding the infected cells (Figs. 4D \& 5C). Adjacent epithelial cells were frequently attenuated and partially applied to cells exhibiting pathognomonic changes. As the infection progressed, there was increased epithelial hyperplasia and dysplasia associated with the infected cells.
Typical WSIV-infected cells were first detected in the olfactory organ at $4 \mathrm{~d} \mathrm{PC}$, followed by their presence in the gills at $5 \mathrm{~d} \mathrm{PC}$ (Fig. 5C) and the most severe and extensive gill lesions occurred between 10 and $14 \mathrm{~d}$ PC. Branchial lesions characterized by diffuse regions of epithelial hyperplasia and/or dysplasia coincided with 
Fig. 5. Acipenser transmontanus. Light micrographs of white sturgeon iridovirus (WSIV) lesions (arrows) in (A) barbels $(6 \mathrm{~d}$ postchallenge, $\mathrm{PC}$ ), (B) esophagus (10 d PC), (C) gill (5 d PC), and (D) skin (8d PC). Note extensive hyperplasia and dysplasia of the esophageal and integumentary epithelium (B, D) and resultant thickening compared to normal epithelium ( $D, n e$ ). The majority of infected cells exhibit varying degrees of separation from the adjoining tissues due to a translucent pericellular cisternum (A, B, C). Scale bar $=250 \mu \mathrm{m}$
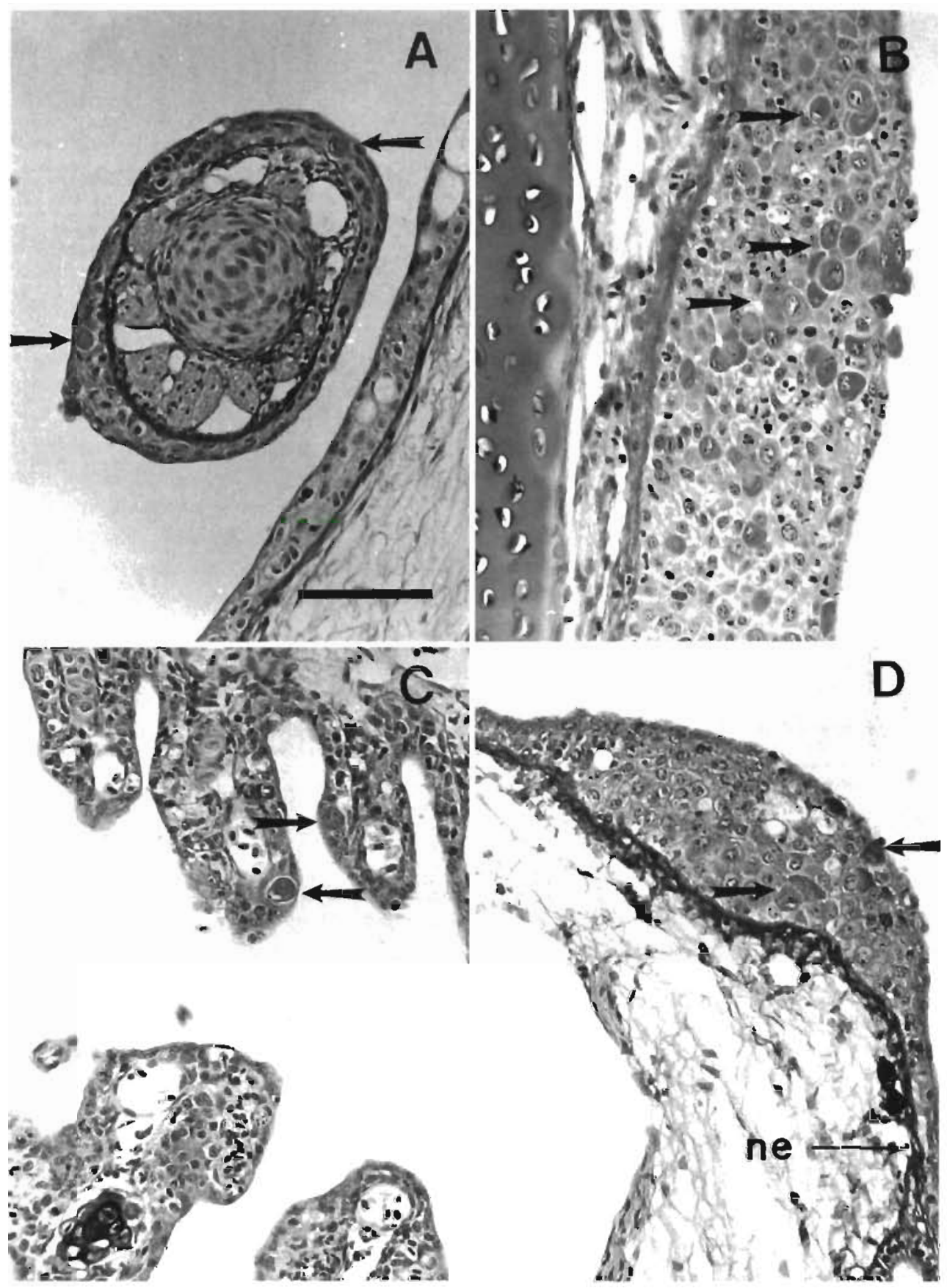

the onset of clinical signs at approximately $12 \mathrm{~d}$ PC. Midto late stages of infection in the gills were marked by the coalescence of necrotic foci that often contained scattered or clustered infected cells. Non-specific focal hyperplasia of the skin and gills of control fish was occasionally seen throughout the study period but was not associated with pathognomonic changes. Infectious WSIV was first confirmed in gill tissues beginning at $5 \mathrm{~d}$ $\mathrm{PC}$ although virus concentrations were evidently low since the CPE often required up to $8 \mathrm{wk}$ to develop.
The integument, including the barbels (Fig. 5A), rostrum, lips and fins (Fig. 5D) exhibited histopathological evidence of infection, but bacterial and fungal contamination often precluded virus isolation. Histopathological signs of infection in the esophagus and oropharynx were initially observed at $6 \mathrm{~d}$ PC and the lesions were similar to those observed in the olfactory and branchial tissues. Infectious WSIV was isolated from pooled esophageal samples by $8 \mathrm{~d}$ PC. 
The livers of the majority of control fish were light pink and the hepatocyte cytoplasm appeared foamy due to the presence of numerous vacuoles. Livers and other internal viscera of challenged fish were extensively examined but no consistent or specific histopathological signs of WSIV infection were detected. The livers of challenged fish appeared for the most part to be smaller and darker than control livers. Microscopic examination revealed these changes to be associated with fewer and smaller cytoplasmic vacuoles within generally smaller hepatocytes. Additional PAS stains indicated that intracytoplasmic glycogen vacuoles in the livers of challenged fish were aggregated and condensed compared to controls. Infectious WSIV was first isolated from livers after approximately 2 wk PC, whereas virus was isolated from kidney tissues beginning at about $7 \mathrm{~d} \mathrm{PC}$ and was sporadically detected in spleen samples at 7 and $25 \mathrm{~d}$ PC. Virus was not detected in any blood samples or tissues of the control fish.

\section{DISCUSSION}

In vitro and in vivo experiments demonstrated that WSIV has certain properties that are similar but others that differentiate it from both the systemic iridoviruses (Ranavirus) and lymphocystis (FLDV) agents from fish. While WSIV resembles these other fish viruses in the family Iridovirus with respect to virion shape, virion size, target cell and lethality, when considered collectively, they differentiate WSIV from both the systemic iridoviruses and FLDV.

The replication of WSIV was improved using a newly developed line (WSGO) from gonad tissues. A bath challenge of white sturgeon fry with virus from cell cultures demonstrated that WSIV targets cells in the gills, skin and chemosensory epthelium. Involvement of the chemosensory tissues is suggested as the cause for cessation of feeding that precedes a progressively lethal wasting syndrome observed in episodes among farm-reared white sturgeon

In the current study we developed 5 new cell lines bringing the total number of lines from white sturgeon to 8 (Hedrick et al. 1992b). Among these cell lines the newly established WSGO line shows the best ability to replicate WSIV. However, the amount of WSIV produced by any of these lines is substantially (100- to 1000 -fold) below that observed with a second virus, WSHV-2, from white sturgeon (Watson et al. 1995) and that observed with the systemic iridoviruses from several fish species (Langdon et al. 1986, 1989, Ogawa et al. 1990, Nakajima et al. 1995). The more rapidly lytic $\mathrm{CPE}$ of the systemic iridoviruses contrast to WSIV, which induces a slower cellular change including enlargement, pseudosyncytium formation and detachment from adjacent cells and the substrate This cellular hypertrophy however, is far less than that observed with FLDV, which, by unknown mechanisms arrests cell division but not cell growth (Wolf 1988).

Cellular changes in WSIV-infected WSGO cells correlated to phases of viral multiplication beginning with early viral-directed protein synthesis to final virion maturation. Early CPE, characterized by vacuolation and refractile borders, are indicative of early viral synthesis, which is followed by the observation of numerous virus assembly sites. Large fully mature virions with dense nucleoids begin appearing after $7 \mathrm{~d}$ at $15^{\circ} \mathrm{C}$. The ultrastructure of the mature virion of WSIV resembles that of other iridoviruses with respect to size dud shape of the riucleoid, a coiled filamentous strand containing viral DNA (Devauchelle et al. 1985). The density and dimensions of the nucleoid of WSIV suggest a step-wise maturation process similar to that associated with carp gill necrosis virus, an iridovirus once thought to be associated with gill disease in cyprind fish (Shchelkunov \& Shchelkunova 1984). Based on observations of FV-3, the viral DNA strand forms a concatemer as it exits the cell nucleus, followed by insertion into the capsid by a process of 'headfull-packaging' (Murti et al. 1985). We observed partially formed empty capsids that later appeared to have been filled with a dense material, presumably the nucleoid (Fig. 2C, D), suggesting similar mechanisms may occur with WSIV. The internal envelope associated with the WSIV and FV3 may differ from the second envelope surrounding the capsid with respect to content of structural proteins (Devauchelle et al. 1985, Murti et al. 1985). The possession of an internal membrane and a capsid envelope has also been identified in several other iridoviruses including epizootic hematopoietic necrosis virus (EHNV) (Hyatt et al. 1991) and FLDV (Flügel 1985). The virion of WSIV further resembles FLDV by possessing a double capsid envelope (Anders 1989). The origins of the internal membrane and external envelopes of FLDV and WSIV are not known but, because neither virus has ever been observed to acquire an external envelope by budding through the plasma membrane, it is probable that capsid envelopment occurs in the cytoplasm. This hypothesis was in part supported by our observation of cytoplasmic bodies, presumably viral ASs, comprised of stacked unit membranes closely resembling the capsid envelope (Fig. 2C).

Both WSIV and FLDV share slower replication rates, lower viral production, limited extracellular release and extended survival of the host cell (Walker \& Hill 1980, Anders 1989) when compared to the systemic or FV-3-like iridoviruses. The systemic iridoviruses cause fatal infections characterized by endothelial and hema- 
topoietic necrosis in several cultured and 1 wild fish species (Eaton et al. 1991, Nakajima et al. 1995). These agents possess morphological, biochemical and serological characteristics in common with the amphibian iridovirus FV-3 (Eaton et al. 1991, Hedrick et al. 1992a, Hengstberger et al. 1993) but not with either WSIV or FDLV. These systemic agents, including EHNV, sheatfish iridovirus and red sea bream iridovirus (RSIV), proliferate rapidly over a broad range of temperatures and cell lines (Berry et al. 1983, Langdon et al. 1986, Ogawa et al. 1990, Nakajima et al. 1995). Rapid cell death and budding from plasma membranes allows viral transmission from infected cells and infected hosts (Hengstberger et al. 1993). In contrast, WSIV produces only about $10^{6} \mathrm{TCID}_{50} \mathrm{ml}^{-1}$ over a 6 to $8 \mathrm{wk}$ incubation period at $15^{\circ} \mathrm{C}$, nearly all of which stays cell associated.

Comparisons of in vitro and in vivo infections of WSIV aid in understanding important aspects of the complex relationship between this parasite and its host. Both WSIV and FLDV induce chronic or slow developing or recurrent diseases in their hosts. These characteristics of WSIV cause it to be especially difficult in hatcheries where stress factors typical of high density fish culture may induce recrudescence among viral carriers, which in turn precipitates recurrent epizootics (LaPatra et al. 1994). In contrast to the systemic iridoviruses which are efficiently released from infected cells, WSIV may spread via cell-to-cell contact as shown by pseudosyncytium formation in vitro. Water-borne transmission of WSIV between juvenile sturgeon has been demonstrated (Hedrick et al. 1990, $1992 \mathrm{~b}$ ) and this may occur by passive sloughing of virus-laden epithelial cells into the water column. Surfaces of the fish that become abraded by contact with the aquarium or other fish could become portals of entry for virus from the water. Tissues of the skin, gills, nares, barbels, and esophagus constantly exposed to water would then provide initiation sites for new infections as well as sites best used for diagnostic procedures to detect WSIV (Watson 1996).

The key target cells of WSIV are associated with tissues involved in osmoregulation and respiration (skin and gills). Changes to cells in these tissues would result directly in their loss of function (Schliwa 1975). Secondarily, loss of the microvillar ridges and therefore the protective mucus layer (Karnaky 1992) may predispose these tissues to subsequent colonization by other pathogens.

Impairment of the sensory epithelium of the barbels and olfactory organs would alter touch, taste and smell (Hara 1993), senses important in white sturgeon to identify congeners, avoid predators and recognize food (Pyatkina 1976, Buddington \& Christopherson 1985). Microscopic lesions induced in these tissues by WSIV could lead directly to changes in feeding behavior, with resulting deterioration of condition and growth as observed in white sturgeon. In wild white sturgeon, WSIV lesions could potentially interfere with nongustatory olfactory functions that control navigation and homing (Hasler \& Scholz 1983).

Acknowledgements. This paper was funded in part by the California Department of Fish and Game and by a grant from the National Sea Grant College Program, National Oceanic and Atmospheric Administration, U.S. Department of Commerce, under grant number NA36RG0537, project number R/A.89 through the California Sea Grant College, and in part by the California State Resources Agency. The views expressed herein are those of the authors and do not necessarily reflect the views of NOAA or any of its sub-agencies. The U.S. Government is authorized to reproduce and distribute for governmental purposes. The authors also thank Mr Robert Munn for electron microscopic expertise.

\section{LITERATURE CITED}

Anders K (1989) Lymphocystis disease of fishes. In: Ahne W, Kurstak E (eds) Viruses of lower vertebrates. SpringerVerlag, Berlin, p 141-159

Aubertin A (1992) Family Iridoviridae Classification and nomenclature of viruses. Arch Virol (Suppl) 2:132-136

Berry E, Shea T, Gabliks J (1983) Two iridovirus isolates from Carassius auratus L. J Fish Dis 6:501-510

Buddington R, Christopherson J (1985) Digestive and feeding characteristics of the chondrosteans. In: Binkowski $F$, Doroshov $S$ (eds) North American sturgeons. Dr W Junk Publishers, Dordrecht, p 31-41

Carey T, Pritchard G (1995) Fish health protection: a strategic role in Canadian fisheries management. $N$ Am J Fish Manag 15:1-13

Conte F, Doroshov S, Lutes P (1988) Hatchery manual for the white sturgeon Acipenser transmontanus with application to other North American Acipenseridae. Publ. \#3322, Cooperative Extension, Division of Agriculture and Natural Resources, University of California, Davis

Devauchelle G. Stoltz D, Darcy-Tripier (1985) Comparative ultrastructure of Iridoviridae. Curr Top Microbiol Immunol $116: 1-21$

Eaton B, Hyatt A, Hengstberger S (1991) Epizootic hematopoietic necrosis virus: purification and classification. J Fish Dis 14:157-169

Fänge $\mathrm{R}$ (1986) Lymphoid organs in sturgeons (Acipenseridae). Vet Immunol Immunopath 12:153-161

Flugel R (1985) Lymphocystis disease virus. Cur Top Microbiol Immunol 116:133-15

Hara T (1993) Chemoreception. In: Evans D (ed) The physiology of fishes. CRC Press, Boca Raton, FL, p 191-218

Hasler A, Scholz A. (1983) Olfactory imprinting and homing in salmon. In: Hasler A, Scholz A (eds) Olfactory imprinting and homing in salmon. Zoophysiology, Vol 14. SpringerVerlag, New York, p 3-40

Hedrick RP, Groff J, McDowell T, Wingfield W (1990) An iridovirus infection of the integument of white sturgeon Acipenser transmontanus. Dis Aquat Org 8:39-44

Hedrick RP, McDowell T, Rosemark R, Aronstein D, Lannan. CN (1991) Two cell lines from white sturgeon. Trans Am Fish Soc 120:528-534 
Hedrick RP, McDowell TS, Ahne W, Torhy C, de Kinkelin P (1992a) Properties of three iridovirus-like agents associated with systemic infections of fish. Dis Aquat Org 13: 203-209

Hedrick RP, McDowell TS, Groff JM, Yun S, Wingfield WH (1992b) Isolation and some properties of an iridovirus-like agent from white sturgeon Acipenser transmontanus. Dis Aquat Org 12:75-81

Hengstberger S, Hyatt A, Speare R, Coupar B (1993) Comparison of epizootic haematopoietic necrosis and Bohle iridovirus, recently isolated Australian iridoviruses. Dis Aquat Org 15:93-107

Hetrick F, Hedrick RP (1993) New viruses described in finfish from 1988-1992. Annu Rev Fish Dis 3:187-207

Humason G (1979) Animal tissue techniques. WH Freeman \& Co, San Francisco

Hyatt A, Eaton B, Hengstberger S, Russel G (1991) Epizootic haematopoietic necrosis virus: detection by ELISA, immunohistochemistry and immunoeiectronmicroscopy. $\mathrm{J}$ Fish Dis 14:605-617

Karnaky K (1992) Teleost osmoregulation: changes in the tight junction in response to the salinity of the environment. In: Cereijido $M$ (ed) Tight junctions. CRC Press, Boca Raton, FL, p 175-185

Langdon $J$ (1989) Experimental transmission and pathogenicity of epizootic haematopoietic necrosis virus (EHNV) in redfin perch, Perca fluviatilis L., and 11 other teleosts. J Fish Dis 12:295-310

Langdon JS, Humphrey JD, Williams LM, Hyatt AD, Westbury HA (1986) First virus isolation from Australian fish: an iridovirus-like pathogen from redfin perch, Perca fluviatilis L. J Fish Dis 9:263-268

LaPatra SE, Groff JM, Jones GR, Holt RA, Hauck AK, Hedrick RP (1994) Occurrence of white sturgeon iridovirus infections among cultured white sturgeon in the Pacific Northwest. Aquaculture 126:201-210

Editorial responsibility: Jo-Ann Leong,

Corvallis, Oregon, USA
Murti K, Goorha R, Granoff A (1985) An unusual replication strategy of an animal virus. Adv Virus Res 30:1-19

Nakajima K, Maeno Y, Fukudome M, Fukuda Y, Tanaka S, Matsuoka S, Sorimachi M (1995) Immunofluorescence test for the rapid diagnosis of red seabream iridovirus infection using monoclonal antibody. Fish Pathol 30(2):115-119

Ogawa M, Ahne W, Fischer-Scherl T, Hoffmann RW, Schlotfeldt HJ (1990) Pathomorphological alterations in sheatfish fry Silurus glanis experimentally infected with an iridovirus-like agent. Dis Aquat Org 9:187-191

PSMFC (Pacific States Marine Fisheries Commission) (1992) White sturgeon management framework plan. Prepared by the White Sturgeon Planning Committee, PSMFC, Portland, OR

Pyatkina G (1976) Receptor cells of various types and their proportional interrelation in the olfactory organ of larvae and aduits of acipenserid fishes. Tsitilogia 18:1444-1449

Reed L, Muench H (1938) A simple method of estimating fifty percent endpoints. Am I Hy 27.493-4.97

Schliwa M (1975) Cytoarchitecture of surface layer cells of the teleost epidermis. J Ultrastr Res 52:377-386

Shchelkunov I, Shchelkunova T (1984) Results of virological studies on gill necrosis. Symp Biol Hung 23:31-43

Walker D, Hill B (1980) Studies on the culture, assay of infectivity and some in vitro properties of lymphocystis virus. J Gen Virol 51:385-395

Watson $\mathrm{L}$ (1996) In vitro and in vivo properties and pathogenesis of the white sturgeon iridovirus, WSIV, in juvenile white sturgeon, Acipenser transmontanus. PhD thesis, University of California, Davis

Watson L, Yun S, Groff J, Hedrick RP (1995) Characteristics and pathogenicity of a novel herpesvirus isolated from adult and subadult white sturgeon Acipenser transmontanus. Dis Aquat Org 22:199-210

Wolf K (1988) Fish viruses and fish viral diseases. Cornell Press, Ithaca, NY

Submitted: September 3, 1997; Accepted: December 5, 1997 Proofs received from author(s): March 10, 1998 